Print ISSN: 2288-4637 / Online ISSN 2288-4645

doi:10.13106/jafeb.2019.vol6.no3.235

\title{
Does Customer Delight Matter in the Customer Satisfaction-Loyalty Linkage?
}

\author{
Mi Jeong KIM ${ }^{1}$, Chul Ju PARK ${ }^{2}$
}

Received: April 21, 2019 Revised: April 29, 2019 Accepted: June 27, 2019

\begin{abstract}
This research focuses on the relationships among customer satisfaction, delight, and loyalty. Although customer delight is one facet of an affective evaluation that can be predicted from customer satisfaction as cognitive component of the evaluation, there is no empirical examination on the casual relationship among customer satisfaction, delight, and loyalty. This study aims at addressing this gap in the service literature. The research questions are (1) How is customer satisfaction related to customer delight? and (2) Does customer delight matter in the relationship between customer satisfaction and loyalty? Data from a survey of consumers across upscale restaurant and retail bank in Korea were obtained. Our results show that customer satisfaction contributes positively to customer delight, and that customer delight plays a significant role in the relationship between customer satisfaction and loyalty. This chained relationship from customer satisfaction to customer delight to customer loyalty suggests that achieving customer delight represents one of the underlying pathways through which basic or core requirements expected by customers are satisfied. Our finding suggests that service firms need to monitor and manage their levels of customer delight as a performance metric, and delighting customers may be an important strategy to build competitive advantage through customer loyalty.
\end{abstract}

Keywords: Customer Delight, Customer Satisfaction, Customer Loyalty

JEL Classification Code: L83, M30, M31.

\section{Introduction}

Customer satisfaction has long been identified as a key antecedent in marketing literature, but current knowledge fails to explain fully why satisfied customers do not remain loyal and eventually defect (Jones \& Sasser, 1995; Mittal \& Kamakura, 2001; Reichheld, 1996; Seiders, Voss, Grewal, \& Godfrey, 2005; Skogland \& Siquaw, 2004; Yang, 2011). Recently, researchers and practitioners in the field of

* This paper was supported by the Sahmyook University Research Fund in 2019

1 First Author. Assistant Professor, School of Mathematics \& Applied Statistics, Kyungsung University, Korea [Postal Address: 309 Suyeong-ro, Daeyeon-dong, Nam-gu, Busan, 48434, Republic of Korea] Email: mijeong0629@ks.ac.kr

2 Corresponding Author. Professor, Department of Business Administration, Sahmyook University, Korea [Postal Address: 815 Hwarang-ro, Nowon-gu, Seoul, 01795, Republic of Korea] Email: cjpark@syu.ac.kr

(๑) Copyright: Korean Distribution Science Association (KODISA)

This is an Open Access article distributed under the terms of the Creative Commons Attribution NonCommercial License (https://creativecommons.org/licenses/by-nc/4.0/) which permits unrestricted noncommercial use, distribution, and reproduction in any medium, provided the original work is properly cited. services marketing have begun to question fundamental aspects of the relationship between customer satisfaction and customer loyalty (Ngobo, 1999; Dey, Ghosh, Datta, \& Barai, 2015). One such question pertains to why satisfied customers leave the firms. To answer this question, practitioners have argued that service firms should go beyond merely satisfying customers and make attempts to delight the customers.

As a result of practitioners' interests and a key contribution by Oliver, Rust, and Varki (1997) in the academia, a stream of literature has developed around the topic of customer delight over the last two decades. A majority of the studies on delight contributed deeply to understanding the factor structure of delight (Alexander, 2010; Arnold, Reynolds, Ponder, \& Lueg, 2005; Barnes, Beauchamp, \& Webster, 2010; Kim \& Mattila, 2013; Kumar, Olshavsky, \& King, 2001; McNeilly \& Barr, 2006; Oliver et al., 1997; Schneider \& Bowen, 1999; Rust \& Oliver, 2000; Williams \& Anderson, 1999; Yang, 2011) and how satisfaction and delight differ at the individual customer level (Berman, 2005; Barnes et al., 2010; Chitturi, Raghunathan, \& Mahajan, 2008; Chowdhury, 2009; Finn, 2005; Oliver et 
al., 1997). Previous academic studies (e.g., Berman, 2005; Finn, 2005; Oliver et al., 1997) have emphasized customer delight as a distinct emotional response but as related to customer satisfaction. While the literature makes a clear distinction between customer satisfaction and delight (e.g., Arnold et al., 2005; Berman, 2005; Finn, 2005; McNeilly \& Barr, 2006; Oliver et al., 1997), service research has focused primarily on the outcomes of each of them, with little consideration of the customer satisfaction-delight linkage.

The marketing literature shows that satisfaction is a key predictor of loyalty. Nevertheless, Oliver (1999) notes that the direct relationship between satisfaction and loyalty might be misspecified and mediated by other exchange-relevant constructs (Agustin \& Singh, 2005). Based on the cognitive theory of emotions (Bagozzi, Gopinath, \& Nyer, 1999; Oliver, 1999), emotions act as a mediator between cognitive evaluation and response behavior. Customer delight is one facet of an affective evaluation that can be predicted from customer satisfaction as cognitive component of the evaluation. Taken together, we can predict that customer satisfaction affects customer loyalty partially through the mediator of customer delight. To our knowledge, however, there is no empirical examination on the casual relationship among customer satisfaction, delight, and loyalty.

In this study, we aimed at addressing this gap in the service literature. This research focuses on the relationships among customer satisfaction, delight, and loyalty. The research questions in this study are as follows: (1) How is customer satisfaction related to customer delight, (2) Does customer delight matter in the relationship between customer satisfaction and loyalty?

To address these questions, we develop and test a conceptual model that customer satisfaction enables service firms to build a base of delighted customers, which in turn contributes positively to customer loyalty. Specifically, we predict that customer delight partially mediates the relationship between customer satisfaction and customer loyalty.

\section{Conceptual Framework and Hypothesis}

In developing our conceptual framework, we review literature on services marketing, customer satisfaction, and customer delight, all of which are relevant to our research focus. On the basis of this review, we define the key constructs of our framework and describe the theoretical grounds and existing evidence supporting the relationships contained in this framework.

Our framework shown in Figure 1 proposes that the relationship between customer satisfaction and loyalty is better understood by the mediating link of customer delight.

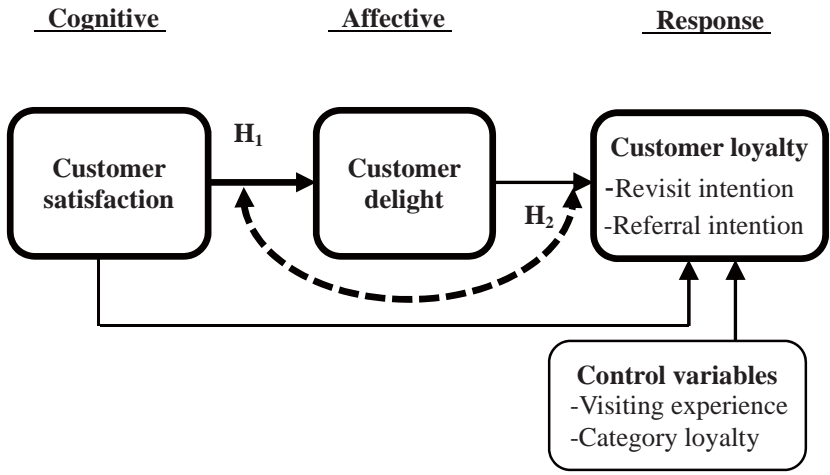

Note: Bolded paths are hypothesized relationships ( $\mathrm{H} 1$ and $\mathrm{H} 2)$. Dashed paths indicate that the depicted relationships are partially mediated by customer delight $(\mathrm{H} 2 \mathrm{a}$ and $\mathrm{H} 2 \mathrm{~b})$. Unbolded paths have been studied previously (The customer satisfaction-loyalty linkage: Anderson \& Mittal, 2000; Boulding Kalra, Staelin, \& Zeithaml, 1993; Cronin, Brady, \& Hult, 2000; Garbarino \& Johnson, 1999; Maxham \& Netemeyer, 2002; Singh \& Sirdeshmukh, 2000; the customer delight-loyalty linkage: Arnold et al., 2005; Bowden \& Dagger, 2011; Chitturi et al., 2008; Dey et al., 2015; Finn, 2005; Hicks, Page, Behe, Dennis, \& Fernandez, 2005; Mattila \& Enz, 2002; Oliver et al., 1997; Schneider \& Bowen, 1999).

Figure 1: Conceptual Framework

\subsection{The Conceptual Difference between Customer Satisfaction and Delight}

Research (e.g. Anderson \& Sullivan 1993; Boulding et al., 1993; Churchill \& Surprenant, 1982; Cronin et al., 2000; Homburg, Koschate, \& Hoyer, 2005; Oliver, 1980) concerning satisfaction has typically adopted a cognitive framework in which a customer compares perceived performance to customer's cognitive expectations. On the other hand, delight is described as an emotional reaction to a service or product that not only satisfies customer's expectation but also provides an unexpected value (Berman, 2005). In the same vein, the psychological and consumer behavior literature (Oliver et al., 1997; Russell, 1980) has also described delight as a profoundly positive emotional state generally resulting from a blend of pleasure and arousal, or more specifically, as a combination of joy and surprise (Arnold et al., 2005; Oliver et al., 1997).

In some delight research, customer delight was conceptualized as the highest level of satisfaction in which delighted customers are more loyal than the merely satisfied (e.g., Keiningham, Goddard, Vavra, \& laci, 1999; Kim \& Mattila, 2013; Rust, Zahorik, \& Keiningham, 1995; Yang, 2011). The most current research, however, has treated customer satisfaction and delight separately (Berman, 2005; Bowden \& Dagger, 2011; Chitturi et al., 2008; Finn, 2005, 2012; Kim \& Mattila, 2013; Wang, 2011). 
Satisfaction research has focused primarily on the disconfirmation of expectations (Spreng, MacKenie, \& Olshavsky, 1996). According to the disconfirmation of expectations model, perceptions of satisfaction arise when customers compare their perceptions of the service performance to their preexisting expectations (e.g., Oliver, 1980). Satisfaction occurs when perceived actual service performance exceeds a consumer's expectations (a positive disconfirmation), and dissatisfaction comes up when perceived service performance does not match the customer's expectation (a negative disconfirmation).

One of the key findings from Oliver et al. (1997) is that the occurrence of delight requires more than simply gaining satisfaction. They find a casual chain whereby a surprisingly positive experience initiated arousal, leading to positive affect and customer delight. They argue that customers delight involves an evaluation of the extent to which the event departs from the customer's experience-based satisfaction norms. Subsequent research (e.g. Berman, 2005; Bowden \& Dagger, 2011; Chitturi et al., 2008; Chowdhury, 2009; Dey et al., 2015; Finn, 2005, 2012; Wang, 2011) has confirmed and expanded the distinction between delight and satisfaction. For example, Berman (2005) notes that satisfaction is primarily a cognitive evaluation, while delight is an emotional reaction; Finn (2005) highlights the distinction between delight and satisfaction constructs as deriving from separate emotional and cognitive sequences. Summing up, satisfaction is based on exceeding expectations, but delight is based on positive unexpected events. While satisfaction occurs when a customer's expectation meets or exceed, delight occurs when perceived actual service performance exceeds a consumer's expectations and the customer experiences unexpected, valuable, and memorable events.

Consistent with these studies, this research conceptualizes customer delight as a distinct and separate evaluative response to the satisfaction response. We define customer satisfaction as a post-consumption evaluation of perceived performance relative to customer's prior performance expectations about quality (Homburg et al., 2005). On the other hand, we define a highly positive form of emotional response to a consumption experience resulting from pleasure, elation, and unexpected levels of surprise (Bowden \& Dagger, 2011; Dey et al., 2015; Finn, 2005; Kim \& Mattila, 2013; Oliver et al., 1997).

\subsection{The Relationship between Customer Satisfaction and Delight}

Although the earlier research (e.g. Finn, 2005; Oliver et al., 1997) tended to take account of the separate effects of customer satisfaction and delight on those outcomes acting in parallel with each other, more recent works (e.g. Chitturi et al., 2008; Finn, 2012) suggested a positive relationship between these two constructs. Chitturi et al. (2008) found a positive correlation between satisfaction and delight; Finn (2012) also showed that customer delight is strongly associated with customer loyalty at satisfaction levels that are above the respondents' average level. However, to our knowledge, only a few studies have been found to investigate the casual relationship between satisfaction and delight. This study argues that even though they are related to each other, satisfaction and delight are two distinct concepts.

Many marketing researchers accept a theoretical framework in which a cognitive evaluation of performance predicts customers' feeling state (e.g. Bagozzi et al., 1999; Lam, Shankar, Erramilli, \& Murthy, 2004; Menon \& Dubé, 2000; Nyer, 1997; Olsen, 2002; Wirtz \& Bateson, 1999). For example, Nyer (1997) suggested that an individual's cognitive appraisal of a situation leads to an affective experience. In the same vein, we suggest that customer delight is one facet of an affective evaluation that can be predicted from customer satisfaction as cognitive component of the evaluation.

A good first step in pursuing a strategy of customer delight is to provide a positive expected level of performance that results in satisfaction and then focus on attractive requirements that yield delight (Berman, 2005). Dissatisfied customers are not likely to be delighted because if basic or core requirements that are expected by customers are unfulfilled, customers will not be delighted (Berman, 2005; Kano, Seraku, Takahashi, \& Tsuji, 1984; Keiningham et al., 1999). Therefore, before delight can be created, acceptable performance on core attributes is necessary (McNeilly \& Barr, 2006). In line with this thinking, Wang (2011) showed customer delight significantly influences repurchase intentions only when core service quality is high. Therefore, some level of customer satisfaction may be necessary for customer delight. This reasoning and the associated evidence lead to the following hypotheses:

$$
\begin{aligned}
\mathbf{H}_{1} \text { : } & \begin{array}{l}
\text { Customer satisfaction has a positive effect on } \\
\text { customer delight }
\end{array}
\end{aligned}
$$

\subsection{The Mediating Role of Customer Delight}

A lot of attempts have been made to study the effects of customer delight on important outcomes such as retention, referral intention, and loyalty, and several studies provide evidence of positive effects of customer delight on customer loyalty (Arnold et al., 2005; Bowden \& Dagger, 2011; Chitturi et al., 2008; Dey et al., 2015; Finn, 2005, 2012; Hicks et al., 2005; Oliver et al., 1997; Schneider \& Bowen, 1999). 
The existing marketing literature shows that satisfaction is an antecedent to loyalty. Reichheld and Teal (1996), however, argued that not all satisfied customers are loyal and some satisfied customers defect from a firm, but when customers are delighted then they are much less likely to leave the firm. This suggestion of Reichheld and Teal (1996) can lead to considering the role of customer delight on the relationship between customer satisfaction and behavioral intentions. In that regard, Oliver (1999) argues that the relationship between satisfaction and loyalty should be mediated by other exchange-relevant constructs (Agustin \& Singh, 2005).

In linking this evidence to the influence of customer delight on customer loyalty with our first hypothesis about the influence of customer satisfaction on delight, a mediating role of customer delight in the customer satisfactionbehavioral intentions linkage might be logically expected; that is, customer satisfaction affects customer delight, which in turn affects customer's behavioral intentions. In other words, customer delight represents the meditational pathway through which customer satisfaction affects behavioral intention.

Rationale for the mediating role of customer delight can be derived from Ajen and Fishbein's (1980) cognition-affectbehavior model; it is a well-investigated framework in attitudinal literature. According to Ajen and Fishbein (1980), attitudes are predictors of behaviors. Consumers form their beliefs of products' attributes through their cognitive-learning; they then generate affective response and attitudes, and finally, the previous attitudes will lead to purchase behavior intention and purchase behaviors (Ajzen \& Fishbein, 1980). In addition, Russell's (1980) model also suggests that affect is the mediating variable of the cognitive process-response behavior relationship. This perspective suggests that customer delight that is customer's emotional response acts as a mediator between customer satisfaction and customer's response behaviors. The foregoing discussion leads to our next hypothesis:

$\mathbf{H}_{2 \mathrm{a}}$ : Customer delight at least partially mediates the relationships between customer satisfaction and revisit intention.

$\mathbf{H}_{2 b}$ : Customer delight at least partially mediates the relationships between customer satisfaction and referral intention.

\section{Research Method}

\subsection{Study Contexts}

To the extent that the proposed relationships among customer satisfaction, delight and loyalty converges across the situational contexts such as sample populations and service industry types, the results can be said to be cross validated (Cronin, Brady, Brand, Hightower, \& Shemwell, 1997). To increase generalizability, we conducted research in two service industries: upscale restaurant and retail bank. Service organizations can be roughly classified into two types: hedonic and utilitarian (Lovelock, 1983). Hedonic services such as vacations and theme parks focus on the consumption experience, reflecting the need for pleasure, fun and excitement (Bigne, Mattila, \& Andreu, 2008). Since several researchers (e.g., Kim \& Mattila, 2013; Stafford, Stafford, \& Day, 2002; Yeung \& Wyer, 2004) noted that upscale restaurants exhibit the characteristics of hedonic services. Conversely, utilitarian services such as automobile repair and medical service are mainly instrumental or functional in nature (Bigne et al., 2008). Previous studies (e.g., Mano \& Oliver 1993; Vanhamme, 2008) chose retail banks as the organizations to satisfy the customers' utilitarian needs. This study offered upscale restaurant services of hedonic services in which the average guest checks were more than US $\$ 20$ and that offered full table service and high-quality ambience, and bank services of utilitarian services excluding online banking and ATM.

\subsection{Data Collection and Samples}

The population of this study was consumers of upscale restaurant service in Korea. Data for the study were collected from adults who have used bank and restaurant services within a 1-month period, respectively, but at two separate time frames. In total, 910 surveys (bank: 460, restaurant: 450) were distributed, and 791 usable surveys (bank: 414, restaurant: 377 ) were returned for a response rate of $86.9 \%$ (bank: $90.0 \%$, restaurant: $83.8 \%$ ). The convenience samples of 791 Korean consumers have a high proportion of women (56.1\%), and the ages range from 20 to 45 years, with a median of 28 years. The job of the sample is varied, with $52.8 \%$ holding the students, $25.2 \%$ the office workers, $12.5 \%$ professionals, $4.7 \%$ service/sales, and $1.2 \%$ self-employers. Income tends toward higher levels; $52 \%$ makes about US \$ or more annually.

\subsection{Measures}

We measured all the items except for control variables on a 7-point Likert-type scale ranging from "strongly agree" to "strongly disagree." The items used in the questionnaire are shown in Table 1.

Customer satisfaction is measured with a four-item scale that closely parallels the previous approaches to measuring customer satisfaction (e.g. Churchill \& Surprenant, 1982; Fornell, Johnson, Anderson, Cha, \& Bryant, 1996; Homburg 
et al., 2005). We focus on a customer's evaluation of his or her experience and reactions that result from a specific transaction between the consumer and a firm, not the overall satisfaction with the cumulative effect of a set of service encounters (Homburg et al., 2005).

To measure customer delight, we first conducted 15 exploratory interviews to underlie the factors that led to delightful service experiences of consumers regarding their experiences with their beauty, medical, bank, restaurant, and hotel service providers. During the interviews, we asked participants to describe satisfactory and delightful experiences they could remember, when, where, and how long the experience was, and what was so satisfactory or delightful about their experiences. We analyzed the interview transcripts, comparing the qualitative data to the 3 items proposed by Finn $(2005,2012)$. This process resulted in 7 measurement items, including 3 revised items from Oliver et al. (1997), Chitturi et al. (2008), and Finn (2005, 2012).

We adopt the scale of customer loyalty developed by Zeithaml, Berry and Parasuraman (1996). The construct validity and nomological validity of this scale have been demonstrated by Zeithaml et al. (1996) and Lam et al. (2004). This scale contains three items relating to revisit intention and three items involving referral intention. We adopt the former three items as measures for the patronage dimension and the latter three items as measures for the recommended dimension of loyalty.

We include category loyalty and previous visiting experience as control. Category loyalty refers to customers' habitual preference for a specific category such as banks, health care services, restaurants, but customer loyalty is to the specific brand or service firm within the category. Bell, $\mathrm{Ho}$, and Tang (1998) suggest that category loyalty reduces the search cost and increases the shopper's ability to recognize deal occasions for the items that a customer wants to buy at the store. A customer who is loyal to a service category such as retail banks or upscale restaurants is likely to be a loyal customer of the specific service brand within the category. To measure category loyalty, we used actual frequencies to visit bank or the restaurant on monthly average basis to control the effect of the loyalty on the category of the bank or the upscale restaurant for the customer for the analysis.

Existing customers have more expertise because they have prior experience with the service providers. Rust and Oliver (2000) suggest that assimilated delight has the strong potential to raise the bar of customer expectations, making delight more difficult to be attained in the future. We expect that new and existing customers will have different psychological and behavioral responses to their experienced service. We define new customers as those visiting the service providers for the first time (during each survey period), whereas existing customers are defined as those who visited the service providers at least once before their current visit. We created a dummy variable that is coded as if new customers are 0 and existing customers are 1.

Because the survey asked respondents to report on both independent and dependent variables within the same survey by self-reported, we used Harmon's one factor test (Podsakoff, MacKenzie, Lee, \& Podsakoff, 2003) to examine whether a common-method bias was present. The items used to measure customer delight and loyalty were entered into a single exploratory factor analysis. The results did not suggest a common-method bias; a single factor did not emerge, nor did one factor account for most of the variance.

\section{Analyses and Results}

\subsection{Measurement Model Results}

Following the work of Anderson and Gerbing (1988), we employ confirmatory factor analysis (CFA) to test the validity of the measures. Overall model statistics show satisfactory results. Specifically, the chi-square value (604.903, d.f. $=158$ ) is significant at 0.05 . The root means square error of approximation (RMSEA) value, however, is 0.061 , which is considered acceptable; the comparative fit index (CFI) and goodness-of-fit index (GFI) are 0.930 and 0.971, respectively, and both are above the suggested fit level of 0.90 (Hair, Black, Babin, Anderson, \& Tatham, 2006).

As we report in Table 1, the CFA results lend some support for the convergent validity for all the measures because all estimated loadings of indicators for the underlying constructs are significant (i.e. smallest $t$-value = 14.794, p <0.01) and greater than 0.5. Cronbach's alpha of the constructs exceeded the 0.7 threshold (Nunnally, 1978). The minimum reliability of these measures is 0.875 , as we reported. In addition, the construct reliability (CR) of all constructs met the respective benchmark of 0.7 . The average variance extracted (AVE) across the constructs exceeds the 0.5 benchmarks (Fornell \& Larcker, 1981). As Table 1 shows, the smallest CR and AVE of the constructs are 0.773 and 0.618 , respectively. 
Table 1: Results of the CFA

\begin{tabular}{|c|c|}
\hline Measures & Factor loading(t-value) \\
\hline \multicolumn{2}{|l|}{ Customer Satisfaction (Cronbach's alpha $=.951 ; C R=.866 ; A V E=.790)$} \\
\hline CS1: All in all, I would be satisfied with this bank/restaurant. & $0.934^{\mathrm{a}}$ \\
\hline CS2: Overall, the service of this bank/restaurant comes up to my expectations. & $0.777(23.511)$ \\
\hline CS3: I think that I did the right thing when I purchased this bank/restaurant service. & $0.904(25.496)$ \\
\hline CS4: This bank/restaurant is exactly what is needed for this service. & $0.916(25.884)$ \\
\hline CS5: My choice to purchase this service was a wise one. & $0.897(25.269)$ \\
\hline CS6: This bank/restaurant provided an ideal experience to me. & $0.895(25.200)$ \\
\hline \multicolumn{2}{|l|}{ Customer Delight (Cronbach's alpha $=0.920 ; C R=0.809 ; A V E=0.618$ ) } \\
\hline CD1: I was delighted with my experience in this bank/restaurant. & $0.582^{\mathrm{a}}$ \\
\hline CD2: I was pleased at services received by this bank/restaurant. & $0.743(16.952)$ \\
\hline CD3: This bank/restaurant service made me elated. & $0.771(14.794)$ \\
\hline CD4: I was thankful for my experience in this bank/restaurant & $0.800(16.252)$ \\
\hline CD5: I was deeply touched at this bank/restaurant service. & $0.881(17.120)$ \\
\hline CD6: My heart felt out by this bank/restaurant service. & $0.885(16.632)$ \\
\hline CD7: This bank/restaurant service has been a tremendous experience. & $0.802(16.298)$ \\
\hline \multicolumn{2}{|l|}{ Revisit Intention (Cronbach's alpha $=0.897 ; C R=0.773 ;$ AVE $=0.747$ ) } \\
\hline PA1: I consider this bank/restaurant as its first choice for bank/restaurant services & $0.918^{\mathrm{a}}$ \\
\hline PA2: I will visit this bank/restaurant in the future & $0.873(33.742)$ \\
\hline PA3: I will use more services provided by this bank/restaurant in the future & $0.798(28.538)$ \\
\hline \multicolumn{2}{|l|}{ Referral Intention (Cronbach's alpha $=0.875 ; C R=0.851 ; A V E=0.749$ ) } \\
\hline REC1: I will say positive things about this bank/restaurant to other friends & $0.951^{\mathrm{a}}$ \\
\hline REC2: I will recommend this bank/restaurant to my friends who seek my advice. & $0.901(41.352)$ \\
\hline REC3: I will encourage friends and relatives to visit this bank/restaurant & $0.729(22.559)$ \\
\hline Visiting experience $^{a}$ & 0.646 \\
\hline Category loyalty & 1.000 \\
\hline
\end{tabular}

Table 2: Correlations and Descriptive Statistics

\begin{tabular}{|l|c|c|c|c|c|c|}
\hline & CS & CD & Revl & Refl & VisitE & CateL \\
\hline 1. Customer satisfaction (CS) & $(0.801)$ & 0.158 & 0.320 & 0.413 & 0.002 & 0.000 \\
\hline 2. Customer delight (CD) & $0.501^{* * *}$ & $(0.664)$ & 0.098 & 0.253 & 0.002 & 0.003 \\
\hline 3. Revisit intention (Revl) & $0.577^{* * *}$ & $0.358^{* * *}$ & $(0.715)$ & 0.430 & 0.012 & 0.001 \\
\hline 4. Referral intention (Refl) & $0.702^{* * *}$ & $0.480^{* * *}$ & $0.765^{* * *}$ & $(0.798)$ & 0.004 & 0.001 \\
\hline 5. Visiting experience (VisitE) & -0.002 & 0.058 & $-0.377^{* * * *}$ & -0.082 & - & 0.014 \\
\hline 6. Category loyalty (CateL) & 0.001 & 0.037 & $0.240^{* * *}$ & 0.054 & $-0.519^{* * *}$ & - \\
\hline Mean & 4.717 & 3.450 & 5.007 & 4.459 & 0.051 & 2.190 \\
\hline Standard deviation & 1.067 & 1.090 & 1.031 & 1.127 & 0.219 & 2.117 \\
\hline
\end{tabular}

Note: The values below the diagonal line are the correlation coefficients among the constructs and the values above the diagonal line mean the square of the correlation coefficients among the constructs. The values inside the parenthesis on the diagonal line are the average variance extracted (AVE) for each construct. $p<0.05,{ }^{* *} p<0.01$.

${ }^{a}$ Dummy variable (new customer $=0$, existing customer $=1$ )

The data also supported discriminant validity of the measures as shown in Table 2. We compared the estimated AVE of each measure with the squared correlation betweenmeasure pairs (Fornell \& Larcker, 1981). In all cases, we found that the AVEs exceeded the squared correlations, further confirming the discriminant validity of the constructs.

\subsection{Results for the Mediating Role of Customer Delight}

In testing the mediating role of customer delight, we used SEM to consider explicitly the possible bias of measurement error on path estimates. Our SEMs not only account for measurement error but also allow for a comprehensive test 
of the hypotheses related to mediation (Luo \& Bhattacharya, 2006).

Table 3 shows the results of the SEMs. H1 predicted that customer satisfaction would positively affect customer delight. Model 1 examines this prediction, and the result is statistically significant, in support of $\mathrm{H} 1$. We assess the significance of the reported SEM path estimates through a bootstrapping approach with 500 resamples. As the $\mathrm{CFI}$, GFI, and RMSEA indicate, Model 1 fits the data well.

$\mathrm{H} 2$ predicted that customer satisfaction would positively influence customer loyalty and that customer delight would mediate this influence. To establish the existence of this mediation effect, four conditions should hold (Luo \& Bhattacharya, 2006): (1) The predictor variable (customer satisfaction) should significantly influence the mediator variable (customer delight); (2) the mediator should significantly influence the dependent variables (customer loyalty); (3) the predictor (customer satisfaction) variable should significantly influence the dependent variables (customer loyalty); and (4) after we control for the mediator variable (customer delight), the impact of the predictor (customer satisfaction) on the dependent variable (customer loyalty) should no longer be significant (for full mediation) or should be reduced in strength (for partial mediation) (Baron \& Kenny, 1986).
As Table 3 shows, Model 1 meets the first two conditions; that is, customer satisfaction affects customer delight. Furthermore, customer delight significantly affects both revisit and referral intention, which is consistent with the previous studies (Chitturi et al., 2008; Dey et al., 2015; Finn, 2005, 2012; Hicks et al., 2005; Oliver et al., 1997). Model 2 qualifies the third condition; the predictor variable of customer satisfaction affects customer loyalty in terms of revisit and referral intention. As Table 3 shows, Model 2 does not include the mediator of customer delight and appears to fit the data reasonably well. The fourth condition holds if the effects of customer satisfaction on customer loyalty become insignificant or less significant after the mediator of customer satisfaction is included. Model 3 results (no mediation model in Table 3) show that the inclusion of customer delight diminishes the strength of the effect of customer satisfaction on customer loyalty. The main effects of customer satisfaction on both revisit and referral intention are significant. Thus, customer delight seems to mediate partially the direct impact of customer satisfaction on customer loyalty. As such, the data provide strong support for $\mathrm{H} 2$, which predicted that customer satisfaction would increase customer loyalty through the mediator of customer delight.

Table 3: SEM Results for Mediation Effects

\begin{tabular}{|c|c|c|c|c|c|}
\hline \multicolumn{2}{|c|}{ Path } & \multirow{2}{*}{$\begin{array}{c}\begin{array}{c}\text { Full Mediation } \\
\text { : Model } 1\end{array} \\
0.525^{\star *}\end{array}$} & \multirow[t]{2}{*}{$\begin{array}{l}\mathrm{CS} \rightarrow \mathrm{CL} \\
: \text { Model } 2\end{array}$} & \multirow[t]{2}{*}{$\begin{array}{c}\text { Nonmediation } \\
\text { : Model } 3\end{array}$} & \multirow{2}{*}{$\begin{array}{c}\text { Partial Mediation } \\
\text { : Model } 4 \\
0.488^{\star *}\end{array}$} \\
\hline $\mathrm{H} 1$ & $\mathrm{CS} \rightarrow \mathrm{CD}$ & & & & \\
\hline & CD $\rightarrow$ Revl & $0.365^{\text {xx }}$ & & $0.097^{\mathrm{nx}}$ & $0.088^{x}$ \\
\hline & $C D \rightarrow$ Refl & $0.482^{* *}$ & & $0.184^{* *}$ & $0.166^{* *}$ \\
\hline & $\mathrm{CS} \rightarrow \mathrm{Revl}$ & & $0.613^{\mathrm{xx}}$ & $0.591^{\mathrm{nN}}$ & $0.577^{n \times}$ \\
\hline & CS $\rightarrow$ Refl & & $0.724^{x x}$ & $0.684^{\mathrm{m*}}$ & $0.647^{n \times}$ \\
\hline & VisitE $^{a} \rightarrow$ Revl & $-0.255^{* *}$ & $-0.222^{* *}$ & $-0.232^{* *}$ & $-0.226^{* *}$ \\
\hline & VisitE $^{a} \rightarrow$ Refl & & & $-0.121^{\text {*** }}$ & $-0.128^{\mathrm{nx}}$ \\
\hline & CateL $\rightarrow$ Revl & & & $0.141^{n x}$ & $0.130^{\mathrm{nx}}$ \\
\hline & CateL $\rightarrow$ Refl & 0.022 & $0.061^{*}$ & $0.056^{*}$ & $0.053^{*}$ \\
\hline $\mathrm{H} 2 \mathrm{a}$ & $\mathrm{CS} \rightarrow \mathrm{CD} \rightarrow \mathrm{Revl}$ & $0.253^{* *}$ & & & $0.081^{*}$ \\
\hline $\mathrm{H} 2 \mathrm{~b}$ & $\mathrm{CS} \rightarrow \mathrm{CD} \rightarrow$ Refl & $0.191^{* *}$ & & & $0.043^{*}$ \\
\hline \multicolumn{6}{|c|}{ Model goodness-of-fit } \\
\hline & $x^{2}$ & 1001.248 & 187.591 & 796.060 & 621.695 \\
\hline & d.f. & 169 & 65 & 168 & 167 \\
\hline & $\Delta \mathrm{X}^{2}(\Delta$ d.f. $)$ & Compared base & & $205.188^{* *}(1)^{b}$ & $379.553^{* *}(2)^{c}$ \\
\hline & GFI & 0.891 & 0.966 & 0.917 & 0.928 \\
\hline & CFI & 0.955 & 0.991 & 0.966 & 0.975 \\
\hline & RMSEA & 0.081 & 0.050 & 0.071 & 0.060 \\
\hline
\end{tabular}

Notes: $\mathrm{CS}=$ customer satisfaction, $\mathrm{CD}=$ customer delight, $\mathrm{BI}=$ behavioral intention, Revl = revisit intention, Refl = referral intention, VisitE $=$ past visiting experience and CateL = category loyalty. Model $2(\mathrm{CS} \rightarrow \mathrm{BI})$ does not include the mediator of customer delight. Model 3 (nonmediation effects) includes the mediator of customer delight. "and "means significance at the significant level of $5 \%$ and $1 \%$, respectively.

a Dummy variable (new customer $=0$, existing customer $=1$ ).

${ }^{\mathrm{b}}$ The results of the difference between Model 1 and Model $3 .{ }^{\mathrm{c}}$ The results of the difference between Model 1 and Model 4. 


\section{Discussion}

What is the effect of customer satisfaction on customer delight? Does customer delight mediate the relationships between customer satisfaction and loyalty? Based on a data set of two service contexts (upscale restaurant and retail bank), our study suggests that the answer to the questions is twofold: (1) customer satisfaction positively affects customer delight, and (2) customer satisfaction affects customer loyalty partially through the mediator of customer delight. These results have implications for both marketing theory and practice.

\subsection{Implications for Theory}

This research clarifies the common issue among many practitioners and academics concerning the differences between customer satisfaction and customer delight. The measurement model results using data for respondents visiting Korean bank and restaurant services lends support the discriminant validity of customer satisfaction and delight. In addition, the test results of casual relationships indicate that customer delight has its own significant effects on customer loyalty. In this sense, the results of this research support the contention of the previous research (Berman, 2005; Dey et al., 2015; Finn, 2005, 2012; Oliver et al., 1997) that customer satisfaction and customer delight are two distinct constructs.

A more important contribution of this research is that we identified a route through which customer satisfaction is related to customer delight. Our results of the significant customer satisfaction $\rightarrow$ customer delight $\rightarrow$ customer loyalty causal chain suggest that customer satisfaction helps build a delighted customer base and that customer delight partially mediates the customer positive behavioral responses to customer satisfaction. This mediating role of customer delight is important for these reasons. It extends the customer satisfaction literature by uncovering a previously ignored outcome (i.e. customer delight) of customer satisfaction. Although prior work has noted that customer satisfaction should affect various kinds of consumer emotional responses, customer satisfaction has not yet been explicitly examined as one such outcome. Overall, this chained relationship from customer satisfaction to customer delight to customer loyalty suggests that achieving customer delight represents one of the underlying pathways through which basic or core requirements expected by customers are satisfied.

\subsection{Implications for Practice}

The research findings in this research could have significant implications for decision markers in service firms.
Our finding that customer delight has its own positive effect on customer loyalty controlling for the effect of customer satisfaction suggests that service firms need to monitor and manage their levels of customers' delight as a performance metric and delighting customer may be an important strategy to build competitive advantage through customer loyalty.

Service features that are not expected or that add unexpected utility performance that is a positive surprise will yield delight. All service firms that implement a delight strategy cannot obtain the desired results of the strategy. Our finding that customer satisfaction contributes positively to customer delight suggests that satisfied customers are likely to be delighted customers. This is, service firms can delight their customers when their service met and exceeded the expectations of the customers. Firms need to assess and confirm whether customers are receiving base level service because delight requires that customers receive more than base level service. Service firms need to concentrate their efforts on delighting customers, and their customers' satisfaction with their service is necessary. Only after acceptable performances on core requirements expected by the customers are fulfilled, service providers can begin to focus on the services that will create delight. It is only when service firms thoroughly recognize their customers that they can begin to create delight.

\subsection{Limitation and Directions for Future Research}

Although our results yield insights into the customer satisfaction-delight-loyalty relationship, there are several limitations to this study and consequently, potential future research directions.

First, on the basis of the core service benefit, we classify retail banks as utilitarian service because the primarily benefit of the service is utilitarian in nature, and upscale restaurants as the core benefit service since its primary benefit is hedonic in nature. However, the service typology may be classified into various attributes such as the importance of employees, customization, the customer's ability to switch firms, employee/customer contact, services directed at people or things, continuous benefits, and differentiation between firms. Future research should consider replicating and extending this research across cultures and industries to provide a more solid understanding of how customer satisfaction influences creating customer delight.

Second, we have focused only on the positive aspects of outcomes of customer satisfaction and delight. But because behavioral intentions as proxy variables of customer loyalty are the construct covering both positive and negative sides (Zeithaml et al., 1996), future research needs to consider 
switching and negative word-of-mouth on a negative note of customer loyalty besides revisit and positive word-of-mouth. We have defined customer loyalty only from an attitudinal perspective. Future research should measure customer loyalty incorporating both attitudinal and behavioral dimensions.

Finally, our understanding of the mediating roles of customer delight might also be enhanced using a longitudinal study to assess the changes in customer's satisfaction and delight through time.

\section{References}

Agustin, C., \& Singh, J. (2005). Curvilinear effects of consumer loyalty determinants in relational exchanges. Journal of Marketing Research, 42(1), 96-108.

Ajzen, I., \& Fishbein, M. (1980). Understanding attitudes and predicting social behavior. Englewood Cliffs, $\mathrm{NJ}$ : Prentice-Hall.

Alexander, M. W. (2010). Customer delight: A review. Academy of Marketing Studies Journal, 14(1), 39-53.

Anderson, E. W., \& Sullivan, M. W. (1993). The antecedents and consequences of customer satisfaction for firms. Marketing Science, 12(2), 125-143.

Anderson, J. C., \& Gerbing, D. W. (1988). Structural equation modeling in practice: $A$ review and recommended two-step approach. Psychological Bulletin, 103(3), 411-423.

Arnold, M. J., Reynolds, K. E., Ponder, N., \& Lueg, J. E. (2005). Customer delight in a retail context: Investigating delightful and terrible shopping experiences. Journal of Business Research, 58(8), 1132-1145.

Bagozzi, R. P., Gopinath, M., \& Nyer, P. U. (1999). The role of emotions in marketing. Journal of the Academy of Marketing Science, 27(2), 184-206.

Barnes, D. C., Beauchamp, M. B., \& Webster, C. (2010). To delight, or no to delight? This is the question service firms must address. Journal of Marketing Theory and Practice, 18(3), 275-283.

Baron, R. M., \& Kenny, D. A. (1985). The moderatormediator variable distinction in social psychological research: Conceptual, strategic, and statistical considerations. Journal of Personality and Social Psychology, 51(5), 1173-1182.

Bell, D. R., Ho, T., \& Tang, C. S. (1998). Determining where to shop: Fixed and variable costs of shopping. Journal of Marketing Research, 35(3), 352-369.

Berman, B. (2005). How to delight your customers. California Management Review, 48(1), 129-151.

Bigne, J. E., Mattila, A. S., \& Andreu, L. (2008). The impact of experiential consumption cognitions and emotions on behavioral intentions. Journal of Services Marketing, 22(4), 303-315.

Bowden, J. L. H., \& Dagger, T. S. (2011). To delight or not to delight? An investigation of loyalty formation in the restaurant industry. Journal of Hospitality Marketing and Management, 20(5), 501-524.

Boulding, W., Kalra, A., Staelin, R., \& Zeithaml, V. A. (1993). A dynamic process model of service quality: From expectations to behavioral intentions. Journal of Marketing Research, 30(1), 7-27.

Chitturi, R., Raghunathan, R., \& Mahajan, V. (2008). Delight by design: The role of hedonic versus utilitarian benefits. Journal of Marketing, 72(3), 48-63.

Chowdhury, U.K. (2009). Delight customers: An exploration into the discriminating factors. Total Quality Management \& Business Excellence, 20(2), 253-266.

Churchill, G. A. Jr., \& Surprenant, C. (1982). An investigation into the determinants of customer satisfaction. Journal of Marketing Research, 19(4), 491504.

Cronin, J. J., Brady, M. K., Brand, R. R., Hightower, R., \& Shemwell, D. J. (1997). A cross-sectional test of the effect and conceptualization of service value. Journal of Services Marketing, 11(6), 375-391.

Cronin, J. J., Brady, M. K., \& Hult, G. T. M. (2000). Assessing the effects of quality, value, and customer satisfaction on consumer behavioral intentions in service encounters. Journal of Retailing, 76(2), 193-218.

Dey, S., Ghosh, S., Datta, B., \& Barai, P. (2015). A study on the antecedents and consequences of customer delight. Total Quality Management \& Business Excellence. DOI: 10.1080/14783363.2015.1049146

Finn, A. (2005). Reassessing the foundations of customer delight. Journal of Service Research, 8(2), 103-116.

Finn, A. (2012). Customer delight: Distinct construct or zone of nonlinear response to customer satisfaction? Journal of Service Research, 15(1), 99-110.

Fornell, C., \& Larcker, D. (1981). Evaluating structural equation models with unobservable variables and measurement error. Journal of Marketing Research, 18(1), 39-50.

Fornell, C., Johnson, M. D., Anderson, E. W., Cha. J., \& Bryant, B. E. (1996). The American customer satisfaction index: nature, purpose, and findings. Journal of Marketing, 60(4), 7-18.

Hair, J. F., Black, B., Babin, B., Anderson, R. E., \& Tatham, R. L. (2006). Multivariate data analysis (6th ed.). New York, NY: Prentice Hall.

Hicks, J. M., Page, T. J. Jr., Behe, B. K., Dennis, J. H., \& Fernandez, R. T. (2005). Delighted consumers buy again. Journal of Consumer Satisfaction, Dissatisfaction and Complaining Behavior, 18, 94-104. 
Homburg, C., Koschate, N., \& Hoyer, W. D. (2005). Do satisfied customers really pay more? A study of the relationship between customer satisfaction and willingness to pay. Journal of Marketing, 69(2), 84-96.

Jones, T. O., \& Sasser, W. E. (1995). Why satisfied customers defect. Harvard Business Review, 73(5), 88-99.

Kano, N., Seraku, N., Takahashi, F., \& Tsuji, S. (1984). Attractive quality and must-be quality. Journal of the Japanese Society for Quality Control, 14(2), 39-48.

Keiningham, T. L., Goddard, M. K. M., Vavra, T. G., \& laci, A. J. (1999). Customer delight and the bottom line. Marketing Management, 8(3), 57-63.

Kim, M. G., \& Mattila, A. S. (2013). Does a surprise strategy need words? The effect of explanations for a surprise strategy on customer delight and expectations. Journal of Services Marketing, 27(5), 361-370.

Kumar, A., Olshavsky, R. W., \& King, M. F. (2001). Exploring alternative antecedents of customer delight. Journal of Consumer Satisfaction, Dissatisfaction and Complaining Behavior, 14, 14-26.

Lam, S. Y., Shankar, V., Erramilli, M. K., \& Murthy, B. (2004). Customer value, satisfaction, loyalty, and switching costs: An illustration from a business-to-business service context. Journal of the Academy of Marketing Science, 32(3), 293311.

Lovelock, C. H. (1983). Classifying services to gain strategic marketing insights. Journal of Marketing, 47(3), 9-20.

Luo, X., \& Bhattacharya, C. B. (2006). Corporate social responsibility, customer satisfaction, and market value. Journal of Marketing, 70(4), 1-18.

Mano, H., \& Oliver, R. L. (1993). Assessing the dimensionality and structure of the consumption experience: Evaluation, feeling, and satisfaction. Journal of Consumer Research, 20(3), 451-466.

McNeilly, K. M., \& Barr, T. F. (2006). I love my accountants, they're wonderful: Understanding customer delight in the professional services arena. Journal of Services Marketing, 20(3), 152-159.

Menon, K., \& Dubé, L. (2000). Ensuring greater satisfaction by engineering salesperson response to customer emotions. Journal of Retailing, 76(3), 285-307.

Mittal, V., \& Kamakura, W. (2001). Satisfaction, repurchase intent, and repurchase behavior: Investigating the moderating effects of customer characteristics. Journal of Marketing Research, 38(1), 131-142.

Ngobo, P. (1999). Decreasing returns in customer loyalty: Does it really matter to delight the customers? Advances in Consumer Research, 26, 469-476.

Nyer, P. U. (1997). A study of the relationships between cognitive appraisals and consumption emotions. Journal of the Academy of Marketing Science, 25(4), 296-304.
Nunnally, J. C. (1978). Psychometric Theory. New York, NY: McGraw-Hill.

Oliver, R. L. (1980). A cognitive model of the antecedents and consequences of satisfaction decisions. Journal of Marketing Research, 17(4), 460-469.

Oliver, R. L. (1999). Whence consumer loyalty. Journal of Marketing, 63(Special Issue), 33-44.

Oliver, R. L., Rust, R. T., \& Varki, S. (1997). Customer delight: Foundations and findings, and managerial insight. Journal of Retailing, 73(3), 311-336.

Olsen, S. O. (2002). Comparative evaluation and the relationship between quality, satisfaction, and repurchase loyalty. Journal of the Academy of Marketing Science, 30(3), 240-249.

Podsakoff, P. M., MacKenzie, S. B., Lee, J., \& Podsakoff, N. P. (2003). Common method biases in behavioral research: A critical review of the literature and recommended remedies. Journal of Applied Psychology, 88(5), 879-903.

Reichheld, F. F. (1996). Learning from customer defections. Harvard Business Review, 74(2), 56-69.

Reichheld, F. F., \& Teal, T. (1996). The loyalty effect. Boston, MA: Harvard Business School Press.

Russell, J. A. (1980). A complex model of affect. Journal of Personality and Social Psychology, 39(6), 1161-1178.

Rust, R. T., \& Oliver, R. L. (2000). Should we delight the customer? Journal of the Academy of Marketing Science, 28(1), 86-94.

Rust, R. T., Zahorik, A. J., \& Keiningham, T. L. (1995). Return on quality(ROQ): Making service quality financially accountable. Journal of Marketing, 59(2), 58-70.

Schneider, B., \& Bowen, D. E. (1999). Understanding customer delight and outrage. MIT Sloan Management, 41(1), 35-45.

Seiders, K., Voss, G. B., Grewal, D., \& Godfrey, A. L. (2005). Do satisfied customers buy more? Examining moderating influences in a retailing context. Journal of Marketing, 69(4), 26-43.

Skogland, I., \& Siguaw, J. A. (2004). Are your satisfied customers loyal? Cornell Hotel and Restaurant Administration Quarterly, 45(3), 221-234.

Spreng, R. A., MacKenie, S. B., \& Olshavsky, R. W. (1996). $A$ reexamination of the determinants of consumer satisfaction. Journal of Marketing, 60(3), 15-32.

Stafford, M. R., Stafford, T. F., \& Day, E. (2002). A contingency approach: the effects of spokesperson type and service type on service advertising perceptions. Journal of Advertising, 31(2), 17-35.

Vanhamme, J. (2008). The surprise-delight relationship revisited in the management of experience. Recherché et Applications en Marketing, 23(3), 113-138. 
Wang, X. (2011). The effect of unrelated supporting service quality on consumer delight, satisfaction, and repurchase intentions. Journal of Service Research, 14(2), 1-15.

Williams, J. A., \& Anderson, H. H. (1999). Customer delight: The beat of a different drummer. Journal of Consumer Satisfaction, Dissatisfaction and Complaining Behavior, 12, 44-52.

Wirtz, J., \& Bateson, J. E. G. (1999). Consumer satisfaction with services: Integrating the environment perspective in services marketing into the traditional disconfirmation paradigm. Journal of Business Research, 44(1), 55-66.
Yang, C. (2011). Identification of customer delight for quality attributes and its applications. Total Quality Management \& Business Excellence, 22(1), 83-98.

Yeung, C., \& Wyer, R. S. (2004). Affect, appraisal, and consumer judgments. Journal of Consumer Research, 31(2), 412-424.

Zeithaml, V. A., Berry, L. L., \& Parasuraman, A. (1996). The behavioral consequences of service quality. Journal of Marketing, 60(2), 31-46. 